\title{
職業選択に及ぼす親の職業的影響
}

一小・中学校教師・大学教師・建築設計士について——

田中宏二*小川

\section{THE INFLUENCE OF PARENTAL OCCUPATION ON CHILDREN'S CAREER CHOICE}

-The Cases of School Teachers, College Profesors, and Architects-

Koji TanaKa AND Kazuo OGawa

\begin{abstract}
The purpose of the present study was to analyze the influence of father's occupation on career choices of their children in connection with children's inheritance of their father's occupation. The subjects were children whose father's occupation has long been either school teacher $(n=267)$, or college professor $(n=363)$, or architect $(n=153)$. The main results were as follows. 1) Compared with the ratios of eldest children choosing any of the three occupations mentioned above other than the father's, those entering the same as their father's weresignificantly high. 2) As for the environmental models as in Holland's theory, the relationships existing between father and son together with father and daughter, was related to his hypothesis. 3) Using the quantification method II as a method of determinant analysis in the process of occupational inheritance, parental expectation and identification, the age of a child and its educational background was found to contribute largely to decide upon its occupational inheritance.

Key words: career choices, occupational inheritance, teachers, architects, Holland's theory
\end{abstract}

問 題

職業構造の変化や社会の開放化に伴い，子供の職業選 択に及ぼす親の職業的影響法下の一途をたどっている (富永，1979）。しかし，親と子の生活のかかわりがある 限り, 親から子へ世代を通した伝達があり, 親の職業的 影響は子供の職業選㘮を基本的に規定し続けることが予 想される。ただ，親の職業的影響は捉え難く微妙である (Super, 1957)だけに，その影響を究明するためには，広 い視点をもつ必要がある。

まず，職業継承性の比較的高い職業に注目して研究を 進めたいと考える。先行研究(小川・田中, 1979)では,

*大分医科大学 (Oita Medical University)

**広島大学 (Hiroshima University)
広範な職業種の継承性の検討の中で, とくに専門的職業 の高い継承志向を確認している。

第 2 の視点は, 研究対象とする標本特性を考慮にいれ ることである。職業的社会化は，一般に当該職における 経年に伴って深まることが明らかにされている (Adler \& Aranya, 1984)。特定の職業化長年従事してきた親を 対象にしてこそ, 内面化された親の職業的世界が子弟の 職業選択に反映されると考える。また，親を対象之する ことにより, 子弟の職業選択に対する親自身の態度を調 べることができる。従来, 子供の認知による研究が多い だけに，これは重要なことである。

第 3 の視点は, 親の職業と子供の職業選㘮の関倸考同 一職業間での直結的な継承性だけでなく, ある種の関連 ある職業への選抧傾向として分析することである。この 
点で, Holland (1973) の職業選択理論が，子供の職業選 択傾向を職業類型の面から捉える視点を与えてくれる。 彼は仮説として，1)多くの人びとは, 現実型, 研究型, 芸術型, 社会型, 企業型, 慣習型の 6 タイプの人格型の いずれかに分類される，2)人びとが生活し，仕事をして いる職業環境には, 人格型に対応した 6 種類のモデル的 な職業環境（人格型と同じ呼称）がある，3) 人は自分の 人格型に調和した職業環境を求め, それを維持する傾向 がある，4)子供の人格型の発達は, 主として親によっ て促進され，しかも親に類似した人格型が発達しやす い，等をあげている。この仮説が妥当であるならば，親 と子は類似の職業環境を求めることが予想される。

第 4 の視点は, 親の職業と子供の職業選択の間には種 種の媒介变数が多重的に影響することが予想されるの で, 多変量解析法による影響過程の分析を行うことであ る。

以上を考慮して, われわれは小・中学校教師, 大学教 師, 建築設計士の専門職をとりあげ, 長年その職に従事 してきた親を調査の対象とする。

小・中学校教師の供給源については古くから多くの研 究があり，比較的高い継承率（10\%台）が認められてい る。

大学教師については, これまで専門職の社会移動の問 題として社会学の分野で扱われている（たとえば新堀・ 有本, 1969）が，心理学的な研究は極めて少ない。この 20 年間に大学教師が 5 万人から 12 万 6 千人へ倍増してい ることや, 現代大学生の最も志向する職業の 1 つである （舘他，1984）ことなどを考えれば, 大学教師の職業心 理学的研究の意義注深い。

また，建築技師はわが国の技師人口中に占める割合が 土木技師についで高く，18万人を擁する代表的な技術的 専門職である。個々の職業として建築技師を取りあげた 研究はその例が殆どないだけに興味ある対象である。建 築技師注事の性格として，芸術的側面（計画，意医な ど）と工学的側面（構造, 施工など）を併せもつュニー

TABLE 1 分 析 対 象

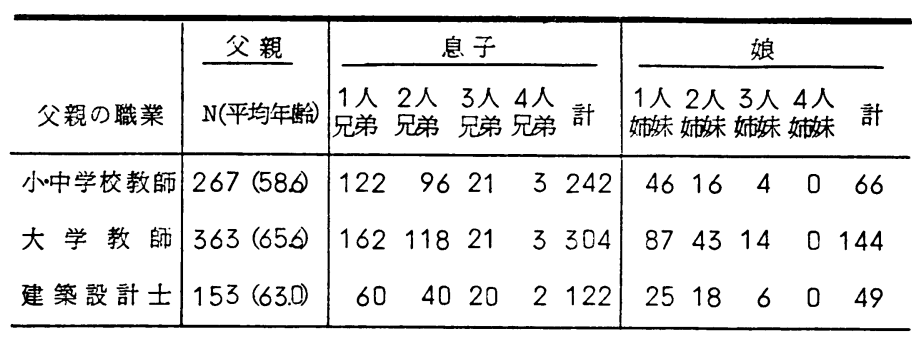

（注）兄弟（姉妹）人数は混性構成によらないで単性践成で区分した。
クな職業である。とくに，前者を主業務とする建築技師 は建築設計士と呼ばれている。

本研究は, 小・中学校教師, 大学教師及び建築設計士 の職業に長年就いてきた親を対象として, 親の職業が子 弟の職業選択にどのような影響を及ぼすかの問題を，子 弟が親と同じ職に就く、いわゆる職業継承性の観点から 究明するものである。

\section{方 法}

調查対象と手続 小.中学校教師の抽出は, 広島県, 愛媛県及び大分県下で昭和 57 年度末に定年退職に準ずる 形で退職を迎えた，推定年齢55歳以上の男教師 595 名を 対象とした。調査時期は，昭和58年11月から12月の間で あった。

大学教師では, 日本教育学会 (昭和 54 年度会員数 2,462 名）または日本心理学会(昭和 57 年度会員数 4,200 名) に 所属する, 推定年齡55歳以上の大学教師 963 名（教育学 442名，心理学521名）を対象とした。調查時期汢，昭和 58年 3 月から 4 月の間であった。

建築設計士では，日本建築家協会（昭和 57 年度会員数 1,162 名）に所属する，推定年龃53歳以上の建築設計士 416 名を対象とした。調查時期は, 昭和 58 年 9 月から 10 月 の間であった。

調査は郵送調査法（無記名）で行われ，回答数は小・ 中学校教師では361通（回収率60.7\%), 大学教師では教 育学248通, 心理学321通の計 569通（回収率59.1\%), 建 築設計士では232通（回收率55.8\%）であった。

分析には，父親の資料で子弟が存在し，かつ子弟（長 子）が職業に就いているものを用いた（TABLE 1)。

調查内容 選択肢方式と自由記述方式を併用した質問 紙法に基づき，その内容は 3 つに分けられる。1)親自身 に関するもの：職業上の専門分野 (あるいは担当教科), 職業経歴(年齢尺度上に識業経歷を記述)，当該職への再 就職意欲（人生をもう1度やり直すことができるならら゙ どんな職に就きたいか), 職業興味検査(Hollandの開発

した Vocational Preference Inventory を翻訳したもので， 6 尺度各14項目からな る。ただし大学教師には实施していない） など，2)子弟に関するもの（親の認知によ る）：第 1 子から第 4 子までの子弟につい て, 子弟の学歴, 専攻, 選択職業及び仕事 内容（自由記述）など，3)親子間に関する もの：親の職業的期待（子弟の高校 $2 \cdot 3$ 年 頃，望㹱子弟に対してどんな職紧を希望ま たは期待していたか), 親の指導様式(1)子 
弟に対して期待を抱き積極的に颈きかけたか一親主導， あるいは子供の自主性を尊重したか一子主導, (2)子弟に 対して親と同じような生き方を望んだか一親同一化，あ るいは親とは異なった生き方を望んだか一親異質化，(3) 子弟の職業選択にあたっての具体的な配慮を 4 段階尺度 で開う), 子弟の選択職業に対する親の満足感（4段骝尺 度）など，計22項目からなる調查票を用いた。

\section{結果}

\section{職業選択行動}

職業継承性 父親の職業及び子弟の性によって程度に 違いはあるが，長子についてみると父親上同じ職業を子 弟が選択する割合 (継承萃) は，父親の職業とは異なる 職業として当該職を子弟が選択する割合に比べて高い （TABLE 2, TABLE 3)。とくに息子の場合,選択した職業 種類の中で父親と同じ職業を選んだものが最も多く，父 親の職業と息子の継承選択 (小・中学校教師, 大学教 師，建築設計士，その他の職業の 4 カテゴリー）の間に は高い関連がある(Cramér 連関係数 $V=.46, \chi^{2}=283.3$, $d f=6, \quad P<.01)$ 。

父親の職業的性質をより細かく分析してみるならば, 小・中学校教師の場合, 小学校教師（大䏊後一貫して当 該教師）の息子では小・中学校教師継承率 $28 \%$, 中学校 教師（一貫して当該教師）の息子では小・中学校教師継 承率14\%を示し, 親の所属する校種上息子の継承の有無 との間に弱い関連が認められる $\left(V=.17, \chi^{2}=4.31, d f=\right.$ $1, P<.05)$ 。大学教師の場合, 専門分野 (教育学と心理学) による継承率及び選択傾向に違いは認められない。建築 設計士の場合，親の専門分野（計画系上構造系）が計画 系 (102名）の息子では建築技師継承率 $46 \%$ を示し，その うち息子の専門分野は計画系 $85 \%$ ，構造系15\%であり， 他方，親が構造系（20名）の息子では建築技師継承率40
\%を示し，そのうち計画系50\%，櫵造系50\%である。親 の専門分野と息子の継承選択分野の間に弱以関連が認め られる $\left(V=.25, \chi^{2}=3.30, d f=1, P<.10\right.$, Yates の修正)。

出生順位 1 人兄弟長男, 2 人兄弟長男, 2 人兄弟次 男の 3 者について継承率の比較を行ったところ, いずれ の親の職業においても出生順位と継承性の関連は高くな い(小.中学校教師 $V=.17$, 大学教師 $V=.10$, 建筑設計 $\pm V=.20)$ 。娘の場合は息子に比べ出生順位との関連は 一層小さい。

親の職業的期待と実現 親が必ずしも具体的な期待職 業をあげなかった割合が，息子では $16 \%-31 \%$ ，娘では 15\%-37\%存在するけれども，何らかの具体的な期待を 表明した場合には，いずれの親の職業においても親之類 似の職業を含めての広義の継承期待をあげる親が最も多 い。小・中学校教師 (親) の教育職 (教的上教盲職) 期 待率は息子 $38.4 \%$, 娘 $53.0 \%$, 大学教師（親）の教育・ 研究職 (教師, 教育職, 研究職) 期待率は息子 $33.9 \%$, 娘 $40.3 \%$, 建築設計士 (親) の建築技師期待率 $39.3 \%$, 娘 $14.3 \%$ である

広義の継承期待をうけた子弟が実際にそれらの期待職 に就く割合 (期待実現率) は, 小・中学校教師の息子 $37.6 \%$, 娘 $77.1 \%$, 大学教師の息子 $44.7 \%$, 娘 $51.7 \%$, 建築設計士の息子 $70.8 \%$, 娘 $42.9 \%$ を示し, かなり高い 割合で継承期待が実現している。

\section{職業選択傾向と Holland 類型}

父親の職業と子弟の選択職業を, Holland 類型の職業 コード (Holland, 1978) に基づいてそれぞれ 6 つの職業 環境型に分類した。まず親の職業では, 小学校教師は社 会型 (S), 理数系中学校教師及び大学教師は研究型 (I ), 建築設計士は芸術型 $(\mathrm{A})$ の各環境型に分類され, 同様に子 弟の選択した職業も 6 つの環境型に分類される。父親と 子弟の環境型の関連をみると (TABLE 4), 息子, 娘共に

TABLE 2 父親の職業と息子（全長男）の職業

\begin{tabular}{|c|c|c|c|c|c|c|c|c|c|c|c|c|c|c|}
\hline 父稲の職蜮 &  & 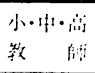 & $\begin{array}{l}\text { 人 } \\
\text { 教 }\end{array}$ & $\begin{array}{l}\text { 建 築 } \\
\text { 技 師 }\end{array}$ & 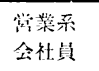 & $\begin{array}{l}\text { 工業采 } \\
\text { 技 師而 }\end{array}$ & 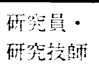 & 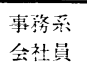 & $\begin{array}{l}\text { 管理系 } \\
\text { 会社員 }\end{array}$ & $\begin{array}{l}\text { 乎拐采 } \\
\text { 公移貟 }\end{array}$ & 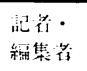 & 鎚行题 & 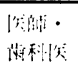 & $\begin{array}{l}\text { その他 } \\
\text { の職業 }\end{array}$ \\
\hline 小・中学校教犃 & $242(100.0)$ & $50(20.7)$ & $3(1.2)$ & $5(2.1)$ & $47(19.4)$ & $23(9.5)$ & $15(6.2)$ & $13(5.4)$ & $7(2.9)$ & $19(7.9)$ & $3(1.2)$ & $12(5.0)$ & $9(3.7)$ & $36(14.9)$ \\
\hline 大学教 師而 & $304(100.0)$ & $31(10.2)$ & $45(14.8)$ & $2(0.7)$ & $44(14.5)$ & $31(10.2)$ & $33(10.5)$ & $27(8.9)$ & $18(5.9)$ & $12(3.9)$ & $12(3.9)$ & $10(3.3)$ & $9(3.0)$ & $30(9.9)$ \\
\hline 建勧設計 & $122(100.0)$ & $0(-)$ & $2(1.6)$ & $55(45.1)$ & $13(10.7)$ & $15(12: 3)$ & $5(+.1)$ & $6(4.9)$ & $6(4.9)$ & $3(2.5)$ & $3(2.5)$ & $3(2.5)$ & $1(0.8)$ & $10(8.2)$ \\
\hline
\end{tabular}

TABLE 3 父親の職業と娘（全長女）の職業

\begin{tabular}{|c|c|c|c|c|c|c|c|c|c|c|c|}
\hline & 娘 & 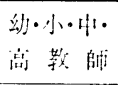 & 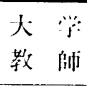 & $\begin{array}{ll}\text { 建 } & \text { 筑 } \\
\text { 技 } & \text { 郈i }\end{array}$ & 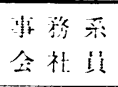 & 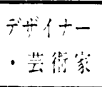 & $\begin{array}{l}\text { 個 人 } \\
\text { 勒 師 }\end{array}$ & $\begin{array}{l}\text { 事務采 } \\
\text { 公務員 }\end{array}$ & $\begin{array}{l}\text { 社会視䀅 } \\
\text { 尃門職員 }\end{array}$ & 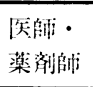 & $\begin{array}{l}\text { そ の他 } \\
\text { の職第 }\end{array}$ \\
\hline 小・中受校教師 & 66( & 38( & $1(1.5)$ & $0(-)$ & $5(7.6)$ & $2(3.0)$ & $2(3.0)$ & $2(3.0)$ & $3(4.5)$ & $5(7.6)$ & $8(12.1)$ \\
\hline 大学教 師 & $144(100.0)$ & $50(34.7)$ & $8(5.6)$ & $2(1.4)$ & $27(18.8)$ & $3(2.1)$ & $13(9.0)$ & $12(8.3)$ & $6(4.2)$ & $7(4.9)$ & $16(11.1)$ \\
\hline 建築设部十 & $49(100.0)$ & $8(16.3)$ & $1(2.0)$ & $5(10.2)$ & $12(24.5)$ & $8(16.3)$ & $1(2.0)$ & $2(4.1)$ & $0(-)$ & $0(-)$ & $12(24.5)$ \\
\hline
\end{tabular}


TABLE 4 父親と子弟（全長子）の職業環境型の関連 卡段：息子

\begin{tabular}{|c|c|c|c|c|c|c|c|c|}
\hline $\begin{array}{l}\text { 父親の } \\
\text { 環境型 }\end{array}$ & 年弟の 環境型 & $\begin{array}{c}\text { 現実型 } \\
\text { (R) }\end{array}$ & $\begin{array}{c}\text { 研究型 } \\
\text { (I) }\end{array}$ & $\begin{array}{c}\text { 芸術型 } \\
(A)\end{array}$ & $\begin{array}{c}\begin{array}{c}\text { 社会型 } \\
\text { (S) }\end{array} \\
\end{array}$ & $\begin{array}{c}\text { 企業型 } \\
\text { (펴) }\end{array}$ & $\begin{array}{c}\text { 賏習型 } \\
\text { (c) }\end{array}$ & 連関度と検定 \\
\hline 小学放教師 (S) & $60(100.0)$ & $3(5.0)$ & $15(250)$ & $6(100)$ & $14(23.3)$ & $13(21.7)$ & $9(15.0)$ & $V=.352$ \\
\hline 理数中学捜孝教的I) & $37(100.0)$ & $\int^{4(10.8)}$ & $16(43.2)$ & $0(-)$ & $3(8.1)$ & $8(21.6)$ & $6(16.2) ?$ & $\chi^{2}=129.34 \quad d f=10$ \\
\hline 大学教師 (I) & $304(100.0)$ & $l_{4}(1.3)$ & $131(43.1)$ & $30(9.9)$ & $31(10.2)$ & 75 (24.7) & $33(10.9) J$ & $p<.01$ \\
\hline 建築設計士 (A) & $122(100.0)$ & $1(0.8)$ & $23(18.9)$ & $62(508)$ & $3(2.5)$ & $25(20.5)$ & $8(6.6)$ & \\
\hline 小学校教師 (S) & $22(100.0)$ & $1(4.5)$ & $1(4.5)$ & $3(13.6)$ & $13(59.1)$ & $0(-)$ & $4(182)$ & $V=.263$ \\
\hline 大学教師 (I) & $144(100.0)$ & $0(-)$ & $25(17.4)$ & $34(23.6)$ & $47(32.6)$ & $6(42)$ & $32(22.2)$ & $\chi^{2}=29.84$ \\
\hline 建築設計士 $(A)$ & $49(1000)$ & $0(-)$ & $2(4.1)$ & $22(44.9)$ & $5(10.2)$ & $5(10.2)$ & $15(30.6)$ & $p<.01$ \\
\hline
\end{tabular}

（注 1) 小・中学校教師は一貫型教師でかつ人数 20 以上の资料のみ扱う.

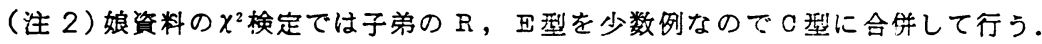

概して親と同一の環境型住就いている割合が高く，両者 に積極的な関連が認められる。すなわち, 親の環境型が 社会型の子弟では小学校教師, 社会科教師, 社会福祉職 員など社会型の職に多く就き，研究型の子弟では理数系 教師, 機械技師, 薬剤士など研究型の職業に, 芸術型の 子弟では建築技師, 新聞記者, デザイナーなど芸術型の 職業に多く就いている。これらの結果は, 親と子の環境 型の類似性を示唆した Holland 仮説を支持している。

\section{職業継承性の規定因}

小・中学校教師と建築設計士の両者に共通な10の説明 変数をとりあげ，子弟が継承するか否かの判別にそれら 諸変数がどの程度の影響を及ぼしているかについて, 数 量化理論第 I 類を適用して検討を行った(TABLE 5)。

継承行動の判別に対する要因寄与の大きさの基準に は，偏相関係数を用いその順位を示した。各カテゴリー に付されたカテゴリーウエイト（数值）の意味は，プラ スの方向のものは継承選択の方向に働き, マイナスの方 向のものは非継承選択の方向に働くことを示す。

判別に寄与する要因の軽重は, 小・中学校教師と建築 設計士で互いによく似ており, 両職業の偏相関倸数の相 関は有意に高い $\left(\mathrm{r}_{\mathrm{s}}=.86, P<.01\right)$ 。寄与の高い要因は, 親 側の要因では指導様式 2 と職業的期待, 子弟側の要因で は年齢と学歴である。それぞれのカテゴリーウェイトの 意味は，前者では親と同じような生き方を願う態度（親 同一化）や親と同じ職に就くことを期待する態度（継承 期待）が，継承選択缏くことを示している。後者では 職業によってその意味が異なっており, 小・中学校教師 の子弟では若年齢層で学部卒が, 建築設計士の子弟では 中年齢層で大学院修了が，それぞれ継承選択慟くこと を示している。なお，年齢要因の働き方に関して疑念が
生じるが, その検討は考察の項で行う。とりあげた10変 数を用いて, 全標本を継承選択と非継承選択に 2 分類す る際の判別成功率注, 小・中学校教師 $77 \%$, 建築設計士 $80 \%$ の值を示した。

\section{考察}

\section{職業継承性}

先の調查 (小川・田中, 1979, 1980)では, 青年の選択 希望による職業継承志向を明らかにしたが, 本報告では 成人の選択行動(実際儎に就いている)による職業継承 性の存在を示すことができた。とくに, 小・中学校教師及 び建築設計士の子弟で核高い継承率が見出され, 本報告 が専門的職業に焦点をあて，さらにその職に長年従事し てきた親を対象としたことは有効であったと思われる。

職業継承の強さは, 同じ専門職であっても個々の職業 により，あるいは性によりかなりの違いが認为られた。 この現象を解釈するにあたり，Gottfredson (1981) の職 業認知の枠組みは示唆的である。彼女は青年の職業認知 の要素に, 性型(男性一女性), 職業威信水準, 職業分野 (Holland 類型) の 3 要素をあげ, 前 2 者を量化した職 業認知図を提示している。本結果をその認知図に対応さ せて考察すると, 小・中学校教師では, 女性度の高い職 業（性度 6 ）であることが娘の継承率を高め, 建築設計 士では, 男性度の高い職業（性度 2 ）であることが息子 の継承率を高める原因になっていると思われる。大学教 師の場合, 性型では中間的（性度 4) であり, 性型より は職業威信水準の高さ（他の 2 職業が60点台に比べ大学 教師の70点台）が，入職の難度に関連し，男女共に継承 率を低めていると考えられる。このように職業間あるい 注男女間の継承率の違いを解明するには, 社会経済的, 
TABLE 5 職業継承規定因の分析（数量化 II 類による分析結果）

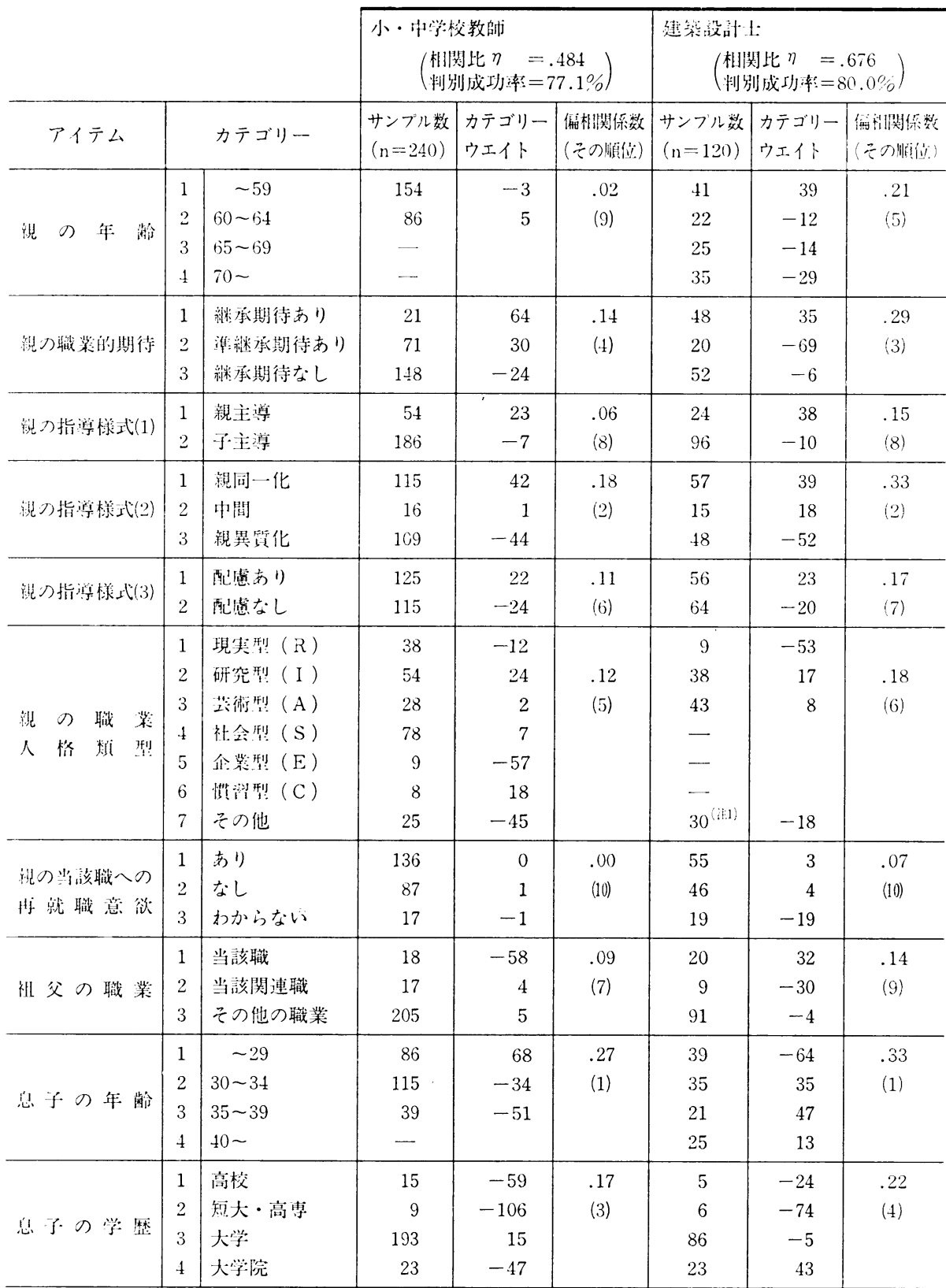



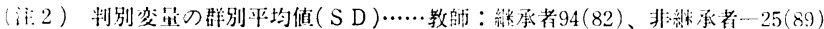

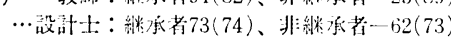

文化的（性役割）な観点からの分析も重要である。

\section{職業選択傾向と Holland 理論}

大学教師 (息子) や建築設計士（娘）の場合, 職業継 承率がいずれも10\%台と低かったにもかかわらず，職業
環境型の一致率では40\%台に高まるなど，Holland 仮説 に立脚した視点注，親の職業的影響の微妙さを捉えるの に有効であった。また，本結果は親の職業之男女大学生 の希望職業の関連を，同様の手続き(職業環境型の対応) 
によって分析した Grandy \& Stahmann (1974) 及び DeWinne et al. (1978)の結果と一致するものであった。 現代の建築技師盖成の多くは, 工学分野で行われてい るが，建築技師の職業的な源流は芸術職であった。この 文脈で調查した Carmon \& Mannheime (1979)は，建築 学専攻の学生の自己イメージが, 芸術家への同一化と技 師への同一化とに分かれることを見出している。手続こ そ異なるが，本結果において建築設計士の子弟(男女共) の約半数が芸術型の職業に就き, さらに息子の多くは芸 術色の濃い計画系建築技術であることは大変興味深い。

\section{職業継承性の規定因}

子供に対する親の職業的態度が, 継承性の重要な規定 因であることを改就確認することができたが，他方で 息子の年齢要因がそれこ同程度の寄与を示したので，そ の点について若干の検討を加えてみたい。年齢要因は, 小・中学校教師では若年齡が継承選択に働き, 建築設計 士では若年齢が非継承選択に㗢いたが，この要因は年齢 自体の性質を示すよりは，むしろその時代性を反映する ものと考えられる。つまり小・中学校教師の若年龄子弟 は最近 10 年間の教職志望人気の高まった時期にあたり, 建築設計士の若年齢子弟注同期間の建築業界の不況期に あたることを考慮沉れると，年齢は時代性の代替指標 であると解するのが妥当と思われる。

したがって，社会経済情勢を反映すると思われる年齢 要因を除去した場合においても, 他の要因による影響度 や働き方に変動が認められないならば, 取りあげた要因 が時代を越えて継承性を規定する要因であると想定でき る。この仮定を検討するために, 小・中学校教師の子弟 で29歳以下の若年齢者のみを全標本から抽出し, 同様の 分析を行った。气の結果, 要因寄与の順位は全標本の場 合とほぼ同じ傾向 $\left(\mathrm{r}_{\mathrm{s}}=.75, P<.05\right)$ を示し, 継承性の判 別成功率 $(83 \%)$ も同じ程度であり，これら諸要因の継承 性規定因としての一般性を確認することができた。

以上の検討から，本報告において得られた主な結果は 次の通りである。1)父親と同じ職業を子弟が選択する割 合は, 小・中学校教師, 大学教師及び建築設計士におい てかなり高いことが認为られた。2)親と子の職業環境の 間に有意な関連が認められ，親の職業的影響が子弟の同 一類型職への選択傾向となって現われた。3)職業継承性 の規定因として, 親の職業的態度, 子弟の年齢及び学歴 が重要であることが示された。

\section{引用文献}

Adler, S., \& Aranya, N. 1984 A comparison of the work needs, attitudes, and preferences of pro- fessional accountants at different career stages. Journal of Vocational Behavior, 25, 45-57.

Carmon, N., \& Mannheime, B. F. 1979 Reference groups and professional self-image: The case of architects. Journal of Vocational Behavior, 14, 169-180.

DeWinne, R. F., Overton, T. D., \& Schneider, L. J. 1978 Types produce types-especially fathers. Journal of Vocational Behavior, 12, 140-144.

Gottfredson, L.S. 1981 Circumscription and compromise: A developmental theory of occupational aspirations. Journal of Counseling Psychology Monograph, 28, 545-579.

Grandy, T. G., \& Stahmann, R.F. 1974 Types produce types: An examination of personality development using Holland's theory. Journal of Vocational Behavior, 5, 231-239.

Holland, J. L. 1973 Making vocational choices: $A$ theory of careers. Englewood Cliffs, N. J. : Prentice-Hall.

Holland, J. L. 1978 The occupations finder. Palo Alto, Calif. : Consulting Psychologist Press.

小川一夫・田中宏二 1979 父親の職業が息子の職業選 択に及ぼす影響に関する研究 教育心理学研究, 27, 272-281.

小川一夫・田中宏二 1980 親の職業が娘の職業選択に 及ぼす影響に関する研究 教育心 理 学 研究, 28 , 328-331.

新堀通也・有本章 1969 大学教授の経歴型の国際比較 社会学評論, 13, 2-21.

スーパー D.E. 日本職業指導学会（訳） 1960 職業 生活の心理学 誠信書房 (Super, D. E. 1957 The psychology of careers. New York : Harper \& Row. )

舘暁夫 · 松本真作 - 渡辺美枝子 - 松本純平 1984 現代 大学生に見る職業志向性の一側面 雇用職業研究, No. 21, 29-38.

富永健一（編） 1979 日本の階層構造 東京大学出版 会

〈謝辞〉本調査にご協力頂いた, 小学校・中学校退職教 諭, 日本教育学会, 日本心理学会並びに日本建築家協会 の会員の皆さんに心から感謝いたします。

〈付記〉本資料の数量化理論 II 類の解析には, 九州大学 大型計算機センターを利用した。

(1985年 1 月 21 日受稿) 